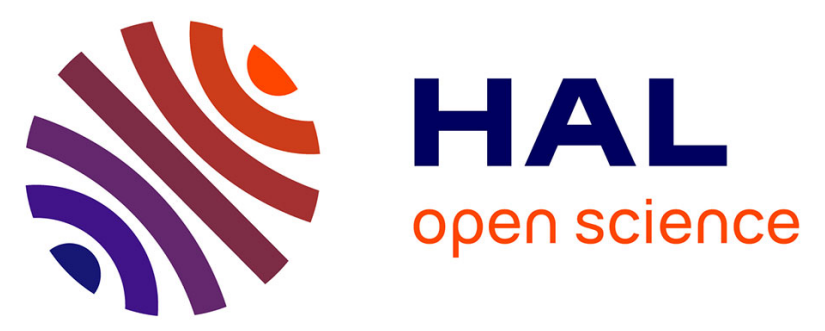

\title{
Antennal responses of an Israeli population of Ostrinia nubilalis Hbn. (Lepid. Pyralidae) males to their female sex pheromone components : magnification of EAG amplitudes with antenna-head preparations connected in series ( 1)
}

Itzhak Moore, Venezia Melamed-Madjar, Lea Muszkat

\section{To cite this version:}

Itzhak Moore, Venezia Melamed-Madjar, Lea Muszkat. Antennal responses of an Israeli population of Ostrinia nubilalis Hbn. (Lepid. Pyralidae) males to their female sex pheromone components: magnification of EAG amplitudes with antenna-head preparations connected in series (1). Agronomie, 1986, 6 (6), pp.517-527. hal-00884905

\section{HAL Id: hal-00884905 \\ https://hal.science/hal-00884905}

Submitted on 1 Jan 1986

HAL is a multi-disciplinary open access archive for the deposit and dissemination of scientific research documents, whether they are published or not. The documents may come from teaching and research institutions in France or abroad, or from public or private research centers.
L'archive ouverte pluridisciplinaire HAL, est destinée au dépôt et à la diffusion de documents scientifiques de niveau recherche, publiés ou non, émanant des établissements d'enseignement et de recherche français ou étrangers, des laboratoires publics ou privés. 


\section{Antennal responses of an Israeli population of Ostrinia nubilalis Hbn. (Lepid. Pyralidae) males to their female sex pheromone compo- nents : magnification of EAG amplitudes with antenna-head series (1) preparations connected in}

Itzhak MOORE, Venezia MELAMED-MADJAR \& Lea MUSZKAT (*)

Department of Entomology

(*) Department of Chemistry of Pesticides and Natural Products, Institute of Plant Protection, Agricultural Research Organization, The Volcani Centre, Bet Dagan, Israel

Responses of male Ostrinia nubilalis to the E- and $\mathrm{Z}$ isomers of 11 -tetradecenyl acetate were studied with the electroantennogram (EAG). The specimens were from a laboratory colony representative of the population endemic in the coastal plain of Israel. The EAGs revealed a greater affinity and specific activity of the $Z$ isomer thus showing that the indigenous population has some of the characteristics of a $Z$ phenotype. Significantly larger signals could be obtained with antennal preparations including the head, whether single or connected in series, than with similar preparations without the head. This magnification appears to be due to a difference between the rates of decay of the 2 types of preparation.

Additional key words : Israel, maize, European corn borer, pest, pheromone phenotype.

Réponses des antennes des mâles d'une population israélienne d'Ostrinia nubilalis $H b n$. (Lepid. Pyralidae) aux constituants de la phéromone sexuelle des femelles : augmentation de l'amplitude des réponses EAG sur les préparations de têtes monoantennaires en série.

Les réactions des mâles d'Ostrinia nubilalis aux isomères acétoxy-1 tétradécène-11 E et acétoxy-1 tétradécène- 11 $\mathrm{Z}$ ont été étudiées au moyen de l'électroantennogramme (EAG). Les spécimens provenaient d'une colonie maintenue en laboratoire et représentant la population endémique dans la plaine côtière d'Israël. Les EAGs ont révélé une affinité et une activité spécifique supérieures pour l'isomère $\mathrm{Z}$ montrant ainsi que la population indigène possède certaines des caractéristiques du phénotype $Z$. Avec des préparations d'antennes comprenant la tête, qu'elles soient unitaires ou montées en série, on a obtenu des signaux significativement plus grands qu'avec des préparations similaires sans la tête. Cette augmentation de l'amplitude des réponses EAG semble due à une différence entre les 2 types de préparations quant à leurs vitesses de dégradation.

Mots clés additionnels : Israël, maïs, pyrale, ravageur, phénotype phéromone.

\section{INTRODUCTION}

It is now well established, mainly through trapping with various blends of the $\mathrm{Z}$ - and $\mathrm{E}$ isomers of 11-

(1) Contribution from the Agricultural Research Organization The Volcani Centre, Bet Dagan, Israel. No. 1357-E, 1985 series. tetradecenyl acetate ( $\mathrm{Z}$ - and $\mathrm{E}-\mathrm{tda})$, that the habitats of Ostrinia nubilalis $\mathrm{Hbn}$. fall into 3 categories. These are the areas in which most or all males are primarily attracted to : $a$ ) the $\mathrm{Z}$ isomer ( $\mathrm{Z}$ strain or phenotypehabitats) $; b$ ) the $\mathrm{E}$ isomer ( $\mathrm{E}$ strain habitats) and c) those wherein both strains tend to be equally distributed (sympatric habitats; for a recent review see ANGLADE et al., 1984). For the countries on Israel's 
borders, only data indicative of $Z$ strain habitats in Egypt are available (ANGLADE et al., 1984). In Israel itself, monitoring $O$. nubilalis populations with $\mathrm{Z}$ and E-tda is in its infancy. To which of the $Z$ or $E$ strains the local populations belong, or whether the strains are sympatric in some area(s), is not yet known.

With the London (Ontario) $\mathrm{Z}$ strain, the electroantennogram (EAG) responses were, at equal doses, greater with the $\mathrm{Z}$ - than with the $\mathrm{E}$ isomer (NAGAI et al., 1977). Likewise, in diagnostic EAG tests on a sympatric population prevalent in Tessin (Switzerland), the $Z$ strain responded more strongly to the $Z$ - than to the $E$ isomer, and vice versa for the $E$ strain (BUECHI et al., 1982). In these instances, there was a correspondence between the EAG responses and the pheromone phenotypes. Whether a similar correspondence can be shown for $O$. nubilalis in Israel depends on the results of field trapping and EAG tests with males representative of the area in which the trapping takes place.

In EAG tests with such males, we compared the antennal responses elicited by various doses of the 2 isomers. This can be done advantageously with serially connected antennae, a technique which, by amplifying the signals, magnifies differences between peripheral stimulants (MOORE, 1981). However, as shown for $O$. nubilalis by NAGAI et al. (1977) and NAGAI (1983), antennal responses rapidly decrease with time. Such a deterioration can be retarded by using whole-body preparations or heads (SCHOONHOVEN, 1974). While EAG characteristics of whole-body preparations have been compared to those of detached antennae by several workers (PRIESNER, 1968 ; ASHER, 1970 ; PAYNE et al., 1970 ; SCHOONHOVEN, 1974), there has not, to the best of our knowledge, been any study dealing with the effects of the head capsule per se on EAG amplitude and decay.

In this report, we define the status of $Z$ - and E-tda as antennal stimuli for an indigenous population of $O$. nubilalis males. We also describe and discuss effects on EAG amplitude and decay obtained by including the head in preparations of these males.

\section{MATERIALS AND METHODS}

The insects were 2-3 day old males from a colony bred for 10 sequential generations on the artificial medium used for Sesamia nonagrioides Lef. (MELAMED-MADJAR \& RACCAH, 1979). The founders of this colony originated from the coastal plain of Israel.

The pheromones were commercial preparations of Z- and E-tda (supplied by the Wolfson Unit of Chemical Entomology, University of Southampton, U.K.) ; impurities did not exceed $0.5 \%$. Required amounts of these components dissolved in hexane were deposited directly onto the inside wall of disposable Pasteur pipettes.

The EAG instrumentation and technique of connecting antennae in series with carboxymethyl- cellulose $(\mathrm{CMC})$ relays were as previously reported (MOORE, 1981) but modified through the use of a small-gauge pheromone/moist air dispensing tube mounted on a microscope mechanical stage (MOORE, 1984). The saline used for dissolving the CMC was as described by ROEDER (1948) but without glucose. It was also used for filling the recording electrode which was a 5 lambda capillary fitted into a holder with a silver/silver chloride half cell (W.P. Instruments Inc.). The indifferent electrode was a silver wire dipped into molten silver chloride. The pheromone was administered through a syringe as a $1 \mathrm{ml}$ puff lasting ca. $0.1 \mathrm{~s}$.

The insect preparations were laid out (fig. 1 and 2 : insets) on a polyethylene rectangle covered with graph paper overlaid with unstretched parafilm. These arrangements made it possible to maintain the geometry as constant as possible. Also, because of the greater sensitivity of the ventral aspect of the antennae (NAGAl et al., 1977), the preparations were arranged as much as possible with this aspect facing the outlet of the pheromone dispensing tube.

Moist air was blown constantly over the preparations at the rate of 0.9-1.0 lpm.

Three experiments were carried out; their objectives and modalities are detailed below.

\section{A. Experiment I}

\section{Objective}

Compare the dose/response curves of Z- and E-tda obtained with serially connected severed antennae as opposed to similar series of antennae still attached to their heads (henceforward designated as « monoantennal » heads).

\section{Technique}

Severed antennae were always cut through the scape and their tips removed. With the monoantennal heads, in addition to one antenna, the proboscis, the maxillary palpi and the tip of the still attached antenna were also removed. With such preparations, care was taken to establish electrical contact only through the occipital foramen and the antennal tip. It was noted that the remaining antenna quickly became motionless and only in 2 instances were atypical receptor potentials observed (discarded data).

The experimental design was an $\mathrm{A} \times(\mathrm{B} \times \mathrm{C} \times \mathrm{S})$ split-plot factorial (KEPPEL, 1973). A - the non repeated factor - represented 2 methods of preparation viz. $a_{1}: 4$ severed antennae in series, and $a_{2}:$ a similar series of monoantennal heads (connection scheme shown by inset in fig. 1). B stood for the 2 isomers and $C$ for 6 dose levels : $0.001,0.01$, $0.1,1.0,10.0$ and $100.0 \mu \mathrm{g}$ of either isomer. The $\mathrm{S}$ factor included 2 lots of 9 preparations (total EAG readings $=2 \times 2 \times 6 \times 9=216$ ) .

The interval between pheromone stimulations was 2-2.5 mn. Time dependent effects were equalized as much as possible by alternating the EAG readings between $a_{1}$ and $a_{2}$ and by randomizing the doses within each preparation. 


\section{B. Experiment II}

\section{Objective}

Compare by a technique different from the above, the signal output of the severed antenna with that of the monoantennal head.

\section{Technique}

Single male preparations treated as in experiment I were used. However, for each individual, the cut antenna and its monoantennal head were aligned on the stage as indicated by the inset of figure 2 . Only 2 readings were taken per preparation: one with the severed antenna, the other with the monoantennal head. Individual variation and time effects were controlled by taking the readings on the same individual and by alternating their sequence from one preparation to the next between the severed antenna and the monoantennal head. Two minutes were allowed between successive readings thereby minimizing adaptation and leaving time enough for rearranging the electrodes (fig. 2 : inset).

The E- and Z-tda loadings were $5 \mu \mathrm{g}$ each. Eighteen preparations per isomer were used as described above.

The significance of the head's effect on the EAG amplitude was tested by the $t$ statistic for paired observations (WALPOLE \& MYERS, 1978).

\section{Experiment III}

\section{Objective}

Detect whether within the first minutes following preparation of the type described in experiment II, depolarizations obtained from single antennae decay at the same rate as those elicited from monoantennal heads.

\section{Technique}

The geometry was the same as in experiment II (see fig. 2 : inset) but only half preparations were used thus reducing the time elapsing until the first stimulation. With both types of preparation, counting time began when one antenna was cut off. The first reading could thus be taken after $3.5 \mathrm{mn}$; this was followed by another three readings taken at $2 \mathrm{mn}$ intervals.

The experimental design was an $\mathrm{A} \times \mathrm{B} \times(\mathrm{T} \times \mathrm{S})$ factorial (KEPPEL, 1973). A and B - the non repeated factors - represented, respectively, the 2 types of preparation and the 2 isomers (each at a dose of $5 \mu \mathrm{g}$ ) ; $\mathrm{T}$, the 4 time intervals and $\mathrm{S}, 4$ lots of 9 preparations each (total $\mathrm{EAG}$ readings = $2 \times 2 \times 4 \times 9=144)$.

\section{RESULTS AND DISCUSSION}

\section{A. Experiment I}

With the exception of 3 pairs of data comparing $E$ to $\mathrm{Z}$ with severed antennae, the $\mathrm{Z}$ isomer consistently elicited greater depolarizations than the other. Thus, the affinity of the antennal receptors for Z-tda was greater than for E-tda; likewise for the specific activity. This is illustrated by figure 1 which also shows that with both isomers, the curves tended to level off with loadings between 10 and $100 \mu \mathrm{g}$. These findings agree with those of NAGAI et al. (1977) for the London strain. Also, our data for the 0.1 to $10 \mu \mathrm{g}$ range agree with those obtained for the same range by BUECHI et al. (1982) with the Tessin Z-strain. On that basis, it appears that the males from our coastal plain have some Z- strain characteristics. Also, recent results of trapping in the coastal plain with various blends of $Z$ - and E-tda have shown a distinct preference of the males for Z-tda as the major blend component (MELAMED-MADJAR et al., unpublished). This suggests that, at least in the coastal plain, the $Z$ strain is preponderant. Regarding the status of the other maize growing areas of Israel, appropriate tests are still needed.

The analysis of variance revealed that the overall effects of the 2 methods of measuring depolarizations differed significantly ( $\mathrm{p}<0.05$ ). This is borne out by

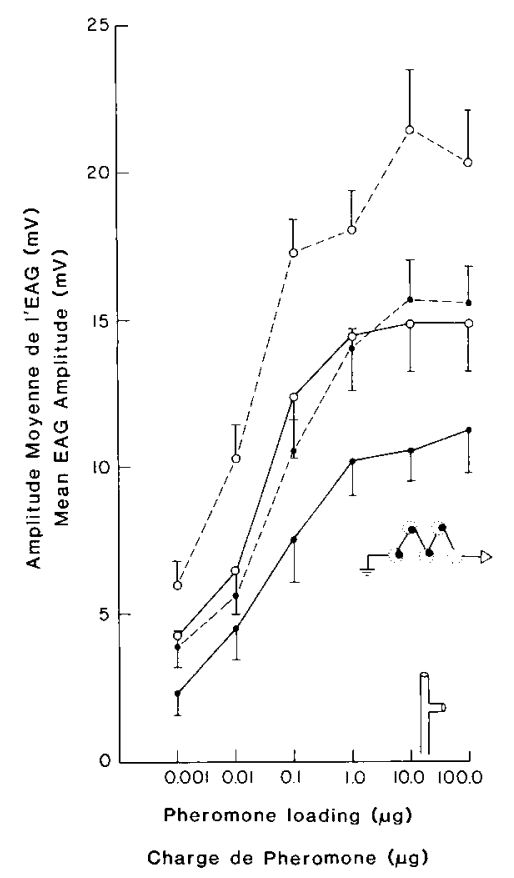

Figure 1

Log dose/EAG responses of male Ostrinia nubilalis to various source loadings of the $E(\bullet)$ and $Z(O)$ isomers of 11-tetradecenyl acetate. Solid lines: 4 antennae connected in series/preparation, dashed lines : 4 monoantennal heads/preparation. Each dot is the mean of 9 readings. Vertical bars represent standard errors.

Inset (top) : schematic representation of electrode connections and preparation geometry for monoantennal heads; dotted circles represent carboxymethylcellulose relays; (bottom): pheromone/ moist air dispensing tube.

Réponses log dose/EAG des mâles d'Ostrinia nubilalis à diverses charges des isomères $E(\bullet)$ et $Z(O)$ de l'acétoxy-1 tétradécène-11. Traits pleins : préparation de 4 antennes montées en série; tirets: préparation de 4 têtes monoantennaires. Chaque point représente la moyenne de 9 résultats. Les barres verticales indiquent les valeurs de l'écart type.

Figures insérées : en haut, schéma de connection des électrodes et de la géométrie des préparations de têtes monoantennaires: les cercles en pointillé représentent les relais de carboxyméthylcellulose ; en bas, tube de distribution phéromone/air humide. 
figure 1 which shows that inclusion of the head in the serial preparations apparently «boosts 》 the depolarizations induced by both isomers beyond what is obtainable with preparations of the same number of antennae but without the heads.

There was a significant interaction ( $p<0.05$ ) between the methods of preparing the insects (factor A) and the pheromone doses (factor C) showing that the effects of $A$ changed with $C$. The locus of this interaction determined according to KEPPEL (1973) revealed that the change became significant ( $\mathrm{p}<0.05$ ) only from $1 \mu \mathrm{g}$ upwards. As apparent in figure 1 , the slopes of the curves corresponding to the 2 types of preparation start diverging between 1 and $10 \mu \mathrm{g}$ : whereas the responses of the antennae tend towards a plateau, those of the monoantennal heads continue to climb. This may reflect a difference between the 2 types of preparation as regards availability and requirements of energy, especially for the restoration of binding site receptivity (ROELOFS \& COMEAU, 1971). At high doses and particularly with the $\mathrm{Z}$ isomer (see experiment III), such requirements are likely to be larger than at low doses. Hence the above discrepancy may be due to the presence of a larger pool of haemolymph in monoantennal heads than in severed antennae, favouring the energetic requirements of the former.

Because of the divergence in the 1 to $10 \mu \mathrm{g}$ range, $5 \mu \mathrm{g}$ loadings of either isomer were used in experiments II and III.

\section{B. Experiment II}

Figure 2 shows that when male preparations were individually stimulated with $5 \mu \mathrm{g}$ of either isomer, the amplitude of the signal at the neck level was some $2 \mathrm{mV}$ larger $(\mathrm{p}<0.01)$ than at the scape level. With one exception, this effect was consistent throughout the tests.

These results confirm those of experiment I regarding the effect of the head. Moreover, they show that this effect is not inherent to serial monoantennal heads only but can also be obtained with similar non serial preparations.

\section{Experiment III}

The main purpose of this experiment was to determine whether the EAG magnification effect might not be due to monoantennal heads decaying at a slower rate than severed antennae. This was done by beginning to monitor the EAG as soon as possible after an antenna had been excised. Under these conditions, the overall effects of the types of preparation (factor A) did not differ significantly $(p>0.10)$. However, the overall effects of the time factor $(T)$ were highly significant $(p<0.001)$. There were also significant interactions between $T$ and $A$ ( $\mathrm{p}<0.001$ ) and between $\mathrm{T}$ and the isomers (factor $\mathrm{B} ; \mathrm{p}<0.01)$ indicating that the effects of the time factor were not the same for the 2 types of preparation and the 2 isomers. In view of this, the sources of these interactions were determined

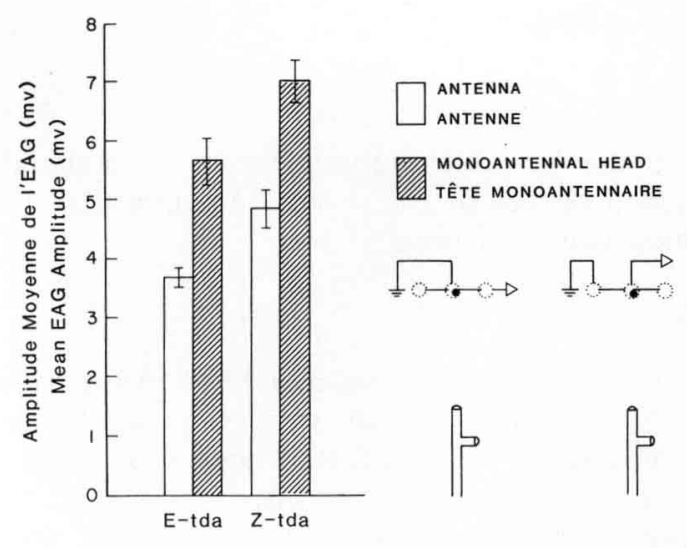

Figure 2

$E A G$ response of the male Ostrinia nubilalis to $5 \mu \mathrm{g}$ loadings of $(Z)$ and (E)-11-tetradecenyl acetate. Each preparation includes the severed antenna and the monoantennal head from the same individual. Each column is the mean of 18 preparations. Vertical bars represent standard errors.

Inset (top) : schematic representation of electrode connections and preparation geometry ; left : for monoantennal head; right : for antenna; dotted circles represent carboxymethylcellulose relays (note space between proximal part of severed antenna and head); (bottom) : pheromone/ moist air dispensing tube.

Réactions électroantennographiques des mâles d'Ostrinia nubilalis à des charges de $5 \mu \mathrm{g}$ de l'acétoxy-I tétradécène-11 (Z) et (E). Chaque préparation comprend une antenne coupée et la tête monoantennaire du même individu. Chaque colonne représente la moyenne de 18 préparations. Les barres verticales indiquent les valeurs de l'écart type.

Figures insérées : en haut, schéma de connection des électrodes et de la géométrie des préparations (à gauche, pour une tête monoantennaire; à droite, pour une antenne); les cercles en pointillé représentent les relais de carboxyméthylcellulose (noter l'espace entre la partie proximale de l'antenne coupée et la tête); en bas, tube de distribution phéromone/air humide.

\section{TABLE 1}

Mean ${ }^{\prime \prime}$ EAG responses of male Ostrinia nubilalis as a function of time, type of antennal preparation and pheromone isomer.

Amplitudes moyennes des réponses EAG des mâles $d$ 'Ostrinia nubilalis en fonction du temps, du type de préparation d'antenne et de l'isomère phéromonal.

\begin{tabular}{lccccc}
\hline & \multicolumn{5}{c}{$\begin{array}{c}\text { Time elapsed after excision } \\
\text { of one antenna (min) }\end{array}$} \\
\cline { 2 - 6 } & 3.5 & 5.5 & 7.5 & 9.5 & $\mathrm{p}$ \\
\hline Single antenna & 5.13 & 4.87 & 4.31 & 4.12 & $<0.001$ \\
Monoantennal head & 5.57 & 5.34 & 5.42 & 5.28 & $>0.10$ \\
E-tda & 4.42 & 4.22 & 4.17 & 4.09 & $>0.10$ \\
Z-tda & 6.28 & 5.99 & 5.56 & 5.32 & $<0.001$ \\
\hline
\end{tabular}

${ }^{1} / \mathrm{mV}$; composite values from factorial experiment.

according to KEPPEL (1973). Relevant data are presented in table 1.

Considering the isomers first, table 1 shows that within the indicated time span, the decrease in the response amplitude was significant in the case of the $Z$ isomer only. Thus Z-tda interacts significantly with time whereas E-tda does not. This could be understood by taking into account the time required by the antennal receptors for repolarization. An examination 
of all the records of the first readings taken in this experiment and their analysis showed that the "50 p. 100 course time"' was significantly longer $(p<0.05$ ) for the $\mathrm{Z}$ isomer $(\overline{\mathrm{x}} \pm \mathrm{S} . \mathrm{E} .=0.70 \pm 0.06 \mathrm{~s})$ than for the $E$ isomer $(\bar{x} \pm$ S.E. $=0.55 \pm 0.04 \mathrm{~s})$. Therefore, as already shown by NAGAI et al. (1977), the Z isomer requires more time for repolarization than the $E$ isomer. The result of such a difference would be to make the probability of some antennal receptors not responding, greater for the $\mathrm{Z}$ isomer than for the $\mathrm{E}$ isomer. With a loading of $5 \mu \mathrm{g}$ which is close to the saturation level (fig. 1), the $2 \mathrm{mn}$ interval between stimulations may not have been quite long enough for complete repolarization in the case of $Z$-tda. The slower repolarization observed with $Z$-tda is yet another characteristic which our population shares with the London strain (NAGAI et al., 1977).

Regarding the types of preparation, table 1 indicates that the interaction between time and this factor was contributed by the single antennae and not by the monoantennal heads. Within $9.5 \mathrm{mn}$, the responses of the antennae decreased significantly whereas those of the monoantennal heads tended to remain at the same level. A similar decay after antennal excision was reported by NAGAI et al. (1977) and NAGAI (1983) for the London strain. Since initially there was no significant difference between the 2 types of preparation (see above and table 1), it appears that the EAG magnification effect was due to the monoantennal heads decaying at a slower rate than the severed antennae. Therefore, in many cases, conventional EAG readings taken on severed antennae can be expected to provide less than the normal amplitude. In this respect, typical receptor potentials derived from preparations including the head would be closer to the norm.

There are 2 plausible interpretations for the difference in the rate of decay of monoantennal heads as opposed to severed antennae. One is the presence of a larger pool of haemolymph in the monoantennal heads which retards their desiccation. The second, linked to the first, could be a greater supply by this pool of the energy source(s) required for signal reception and transduction.

A comparison between the advantages and disadvantages of the various types of EAG preparations most frequently used with Lepidoptera is of practical interest. Whole-body preparations have a longer useful life and provide EAG signals more reproducible than excised antennae (PRIESNER, 1968).
Also, the amplitude of the EAG responses obtained with these preparations is greater than with severed antennae (ASHER, 1970 ; PAYNE et al., 1970). However, with whole-body preparations, signals due to muscular activity interfere with the recordings (SCHOONHOVEN, 1973). In such preparations, movement is prevented by carefully restraining the insect through various means (e.g. see O'CONNELL, 1975). This makes manipulation of intact insects less simple than that of excised antennae (SCHOONHOVEN, 1973) especially when there is an interest in connecting the antennae in series (e.g. when screening for minor pheromone components; MOORE, 1981). Excised antennae have none of these drawbacks but may deteriorate rapidly (SCHOONHOVEN, 1974). As opposed to the above, monoantennal-head preparations increase EAG amplitude without, or hardly any, interfering signals ; their useful life is extended (albeit less than that of intact insects); their manipulation is simple and lends itself to serial connection. Therefore, the use of serial preparations of monoantennal heads should be advantageous when it is desired to obtain larger and more durable signals especially from small insects.

\section{CONCLUSIONS}

1. According to present evidence, the male population of $O$. nubilalis in the coastal plain of Israel very likely belongs to the $\mathrm{Z}$ strain. In other maize growing areas of the country, dominance of the E strain or the occurrence of sympatry cannot be excluded at this stage.

2. Monoantennal heads, whether single or connected in series, provide EAG signals stronger and reproducible for longer periods than those obtainable under the same conditions with excised antennae.

Reçu le 12 mars 1985. Accepté le 4 février 1986.

\section{ACKNOWLEDGEMENTS}

We thank Prof. V. Teichberg (Department of Neurobiology, Weizmann Institute of Science, Rehovot, Israel) for his critical reading of the manuscript and helpful suggestions. We are also indebted to Mrs. M. HAREL for her excellent technical assistance.

\section{REFERENCES}

Anglade P., Stockel J., I.W.G.O. Cooperators, 1984. Intraspecific sex-pheromone variability in the European corn borer, Ostrinia nubilalis Hbn. (Lepidoptera, Pyralidae). Agronomie, 4, 183-187.

Asher W. C., 1970. Olfactory Responses of Dioryctria abietella (Lepidoptera : Phycitidae) to Slash Pine Cones. Ann. entomol. Soc. Am., 63, 474-476.

Buechi R., Priesner E., Brunetti R., 1982. Das sympatrische Vorkommen von zwei Pheromonstammen des Maiszünslers, Ostrinia nubilalis Hbn., in der Südschweiz. Mitt. Schweiz. entomol. Ges., 55, 33-53.
Keppel G., 1973. Design and Analysis : A Researcher's Handbook. Prentice-Hall, Inc., Englewood Cliffs, N.J., 658 p.

Melamed-Madjar V., Raccah B., 1979. The Transtadial and Vertical Transmission of a Granulosis Virus from the Corn Borer Sesamia nonagrioides. J. Invertebr. Pathol., 33, 259-264.

Moore I., 1981. Biological Amplification for Increasing Electoantennogram Discrimination between Two Female Sex Pheromones of Spodoptera littoralis (Lepidoptera : Noctuidae). J. chem. Ecol., 7, 791-798. 
Moore I., 1984. The effects of the antennal flight posture and orientation on the pheromonal stimulation patterns experienced by male Spodoptera littoralis (Lepidoptera: Noctuidae). Chem. Senses, 9, 15-29.

Nagai T., Starratt A. N., McLeod D. G. R., Driscoll G. R., 1977. Electroantennogram Responses of the European Corn Borer, Ostrinia nubilalis, to (Z)- and (E)-11-Tetradecenyl Acetates. $J$. Insect Physiol., 23, 591-597.

Nagai T., 1983. On the Relationship Between the Electroantennogram and Simultaneously Recorded Single Sensillum Response of the European Corn Borer, Ostrinia nubilalis. Arch. Insect Biochem. Physiol., 1, 85-91.

O'Connell R. J., 1975. Olfactory Receptor Responses to Sex Pheromone Components in the Redbanded Leafroller Moth. J. Gen. Physiol., 65, 179-205.

Payne T. L., Shorey H. H., Gaston L. K., 1970. Sex Pheromones of Noctuid Moths : Factors Influencing Antennal Responsiveness in Males of Trichoplusia ni. J. Insect Physiol., 16, 1043-1055.
Priesner E., 1968. Die interspezifischen Wirkungen der Sexuallockstoffe der Saturniidae (Lepidoptera). Z. vergl. Physiol., 61, 263297.

Roeder K. D., 1948. The effect of potassium and calcium on the nervous system of the cockroach Periplaneta americana. J. Cell. and Comp. Physiol., 31, 327-338.

Roelofs W. L., Comeau A., 1971. Sex Pheromone Perception : Electroantennogram Responses of the Red-Banded Leafroller Moth. J. Insect Physiol., 17, 1969-1982.

Shoonhoven L., 1974. Studies on the shootborer Hypsipyla grandella (Zeller) (Lep., Pyralidae). XXIII. Electroantennograms (EAG) as a tool in the analysis of insect attractants. Turrialba. 24 (1), 2428.

Walpole R. E., Myers R. H., 1978. Probability and Statistics for Engineers and Scientists. MacMillan, New York, $580 \mathrm{p}$. 